To be presented at 2003 International Oil Spill Conference, 6 - 10 April 2003

\title{
Assessing Progress and Benefits of Oil Spill Response Technology Development Since Exxon Valdez
}

\author{
Dagmar Schmidt Etkin \\ Environmental Research Consulting \\ 750 Main Street \\ Winchester, MA 01890 USA
}

\author{
Peter Tebeau \\ Potomac Management Group \\ 214 Thames Street \\ Groton, CT 06340 USA
}

\begin{abstract}
This paper describes a simple approach to quantifying progress and benefits associated with improvements in oil spill removal technology over the past decade, focusing on the most significant oil removal technologies: mechanical recovery, dispersant application and in-situ burning. All three technologies have been the focus of research and development (R\&D) efforts since the Exxon Valdez spill. Notable progress has been made in refining the technologies and defining circumstances under which each option will be successful. These accomplishments have been qualitatively described in recent strategic technology assessments. The difficulty that arises in quantitatively predicting future benefits of these advances, is that expected increases in oil removal and associated cost savings are as much a function of specific circumstances of future spills as of advances in spill removal technologies. The specifics of future spills, particularly the larger more troublesome ones, are difficult to predict. In order to obtain representative quantitative estimates of these benefits, a hind-cast technique is demonstrated whereby the advanced technologies are applied to past spill scenarios to determine oil recovery and cost savings that would be realized if these spills were to occur in the future.

\section{INTRODUCTION}

The Exxon Valdez spill, like several major spills before it, underscored the limited capability to remove spilled oil from the marine environment and sparked a concerted US effort to upgrade oil spill countermeasures and cleanup technology. Over the past decade, advances have been made in mechanical recovery (e.g., recovery in fast water, sinking oil), in-situ burning, and dispersants, as described qualitatively in the US Coast Guard (USCG) Oil Spill Response Etkin and Tebeau IOSC 2003 Paper Pre-Publication Copy - DO NOT CITE OR QUOTE 1
\end{abstract}


To be presented at 2003 International Oil Spill Conference, 6 - 10 April 2003

Capability Review (CAPS) (1999), the USCG Oil Spill Prevention, Preparedness and Response (OSPPR) Risk Assessment (2001), and in past International Oil Spill Conferences. What has not been accomplished to date is a quantitative assessment of impacts of technology advancements.

The objective of the analysis is to provide an order of magnitude quantitative estimate of the level of progress and economic benefits associated with oil spill technology advances by examining impacts these technologies would have had in spills that have occurred since Exxon Valdez. The analysis focuses on selected major and more significant medium spills where these response technologies were or could have been employed. Quantitative benefits (costs saved) are estimated based on hypothetical decreased damages associated with more effective oil removal. These include cost savings associated with shoreline cleanup, environmental damage, and socioeconomic impacts that would be prevented or reduced by more effective oil removal.

There is general consensus in the spill response community that significant progress has been made since Exxon Valdez in upgrading oil removal technology and improving resource availability to successfully implement these technologies in the event of a spill. In May 1999, the USCG Office of Marine Safety and Environmental Protection completed a study to determine the adequacy of spill cleanup technology and resource availability to support raising expected oil spill response capabilities on the part of vessel and facility owners. The results of the Response Plan Equipment CAPS Review (referred to henceforth as the CAPS Study) indicated that, based on technology developments and resource availability, a 25\% increase in mechanical recovery response capability was warranted. The study further recommended that contingency plan holders carrying or handling Group II, III, and V products within 50 nautical miles of shore and in areas where dispersants have been pre-approved, should be required to have resources to treat $24,000 \mathrm{bbl}$ of spilled oil within 60 hours of authorization. The study also concluded that technology advances and resource availability for in-situ burning warranted that plan holders 
To be presented at 2003 International Oil Spill Conference, 6 - 10 April 2003

carrying or handling Group II, III, and V products within 50 nautical miles of shore and in areas where in-situ burning has been pre-approved or cleared for expedited approval, should be encouraged to maintain resources to treat $10,000 \mathrm{bbl}$ of spilled oil. This reflects a significant improvement in technology and availability since Exxon Valdez.

Advances in spill response technology for mechanical recovery, dispersants and in-situ burning were addressed in the June 2001 USCG OSPPR Risk Assessment. The study concluded that technology advances had improved the "functional effectiveness" of these oil removal techniques, i.e., the percentage of spilled oil that can be removed from a given spill where the technique can be applied. For mechanical recovery, a functional effectiveness of $10-30 \%$ can generally be realized, with effectiveness levels of $50 \%$ and greater being reached on certain spills. Mechanical recovery is widely applicable to various spill scenarios encountered. Dispersants can be highly effective under the right circumstances and improvements in formulations have improved the application "window of opportunity." However, the option remains applicable to a limited handful of spills, due to current restrictive application criteria. Insitu burning technology has been significantly improved with developments in fire-resistant boom, increased equipment availability, and growing acceptance of the technique. However, like dispersant application, its applicability is limited to a handful of situations.

Granting that improvements in all three removal techniques have been made, the question arises as to how much additional oil might be recovered and how many dollars might be saved in coming years because of these improvements. This is not simply an academic issue, as the continuation of $\mathrm{R} \& \mathrm{D}$ efforts for these technologies may well rest on providing quantitative estimates of these benefits to fiscal authorities. Since the passage of OPA 90 and the initial resurgence in oil spill technology $\mathrm{R} \& \mathrm{D}$, funding has declined steadily. Obtaining additional funding in this area will depend on demonstrating tangible benefits in terms of cost savings. 
To be presented at 2003 International Oil Spill Conference, 6 - 10 April 2003

An obvious question is "How many dollars will be saved in the coming years from technology advances accomplished during the past decade?" The main difficulty in answering this question is that cost savings depend both on technology effectiveness and the circumstances of future spills encountered that are yet unknown. The specific circumstances of a spill are important in that they determine whether a cleanup technique can be applied and the achievable level of effectiveness ( $\%$ oil removal). Key parameters governing cleanup technique applicability and effectiveness are oil type, spill location (including distance from shore and water depth), and weather conditions. Statistical extrapolations of spilled oil recovery and cost savings are difficult because of this sensitivity to specific spill circumstances and the fact that dispersants and in-situ burning have rarely been used. Predictions based on current contingency planning scenarios are difficult as the probability of scenario occurrence is unknown. However, the adage "history repeats itself" suggests using a hind-cast approach whereby past spill scenarios are used to predict potential cost savings and provide insight into benefits that may be realized in the future.

\section{METHODOLOGY}

The first step was to identify a manageable set of spills for analysis. Because estimating the functional effectiveness and applicability of cleanup techniques depends on specific spill factors, the case histories must be reasonably well-documented for the spills analyzed. This analysis builds on previous efforts by focusing on two spill sets described in detail in the USCG CAPS and OSPPR studies. The first spill set is extracted from a larger set examined in the CAPS study, which was in turn taken from an analysis of applicability of mechanical recovery, dispersants, and in-situ burning for spills in 1993 - 1998 by Kucklick and Aurand (1997). Kucklick and Aurand established applicability of the three countermeasures for each spill based on oil type, wind conditions, and distance from shore, as well as applying both existing and expanded criteria for dispersant and in-situ burning authorization. The results are summarized in Appendix A-1 of the CAPS study. For the current analysis, only spills greater than 10,000 gallons were 
To be presented at 2003 International Oil Spill Conference, 6 - 10 April 2003

considered, as it is unlikely that dispersants and in-situ burning would be attempted for spills smaller than this. Table 1 lists the CAPS spills considered and cleanup technique applicability. The second spill set included the more significant US spills since Exxon Valdez addressed in the OSPPR study (Appendix C-2). Table 2 lists the OSPPR spills and applicability of each technique based on general criteria in Kucklick and Aurand (1997). In determining applicability, the general spill circumstances were taken into account (volume, oil type, location) but not exact details. e.g., in the spills considered, dispersants were never actually used because of factors encountered and response decisions. However, if circumstances dictated that dispersants could be used in a similar future spill, the technique was deemed applicable.

The overall strategy was to determine cost savings associated with applying the three oil removal technologies at their previous - pre-Oil Pollution Act of 1990 (OPA 90) - and current (post-OPA 90) levels of effectiveness to the spill sets. The difference in costs represents a quantitative measure of progress in developing each technology. This required selecting general effectiveness levels and specifying a cost savings calculation model. In doing so there were a number of assumptions and speculation that will certainly impact the magnitude of cost savings. It must be noted that the purpose of this exercise is not to precisely determine expected cost savings but to provide some quantitative insight into levels of progress.

The next step was to set response effectiveness levels. The mechanical recovery effectiveness levels (\% removal) assumed for the CAPS spills were those specified in the CAPS study: 20\% for pre-OPA 90 and 50\% for post-OPA 90. For in-situ burning, a conservative effectiveness level of 50\% was applied. For dispersants, conservative effectiveness levels were specified corresponding to the lower effectiveness CAPS study levels with \% removal based on oil type: light oils and crude $-40 \%$, and heavy fuels $-35 \%$. The conservative effectiveness values were chosen in an effort to provide realistic estimates of projected oil removal taking into 
To be presented at 2003 International Oil Spill Conference, 6 - 10 April 2003

consideration oil encounter and treatment rates and the often limited "window of opportunity" for employing dispersants and in-situ burning. Effectiveness levels applied to the OSPPR spills were $10 \%, 20 \%$, and $50 \%$ for mechanical recovery. To reflect pre-OPA 90 effectiveness, values of $10 \%$ or $20 \%$ were assigned to spills where mechanical recovery was applicable; for post-OPA 90 effectiveness, values of $20 \%$ or $50 \%$ were assigned. For dispersant and in-situ burning, the same effectiveness levels used in the CAPS spill analysis were used for post-OPA 90 effectiveness; for pre-OPA 90 it was assumed that neither option would be employed and a lower effective mechanical recovery was assumed. To determine post-OPA 90 costs for spills for which in-situ burning and/or dispersants were not applicable, low-effective mechanical recovery was assumed. For spills deemed untreatable by any option, it was assumed that a mechanical recovery was attempted (i.e., accruing costs) but with no effectiveness and no impact reduction. Including the mechanical recovery costs in the post-OPA 90 dispersant and in-situ burning computations is important, as it means that the cost savings calculated reflect the total net cost savings for the whole spill set with the particular technology. In some cases, there would have been no cost advantage to having alternative technologies available as they were not applicable.

The next step was determining net cost savings associated with the technologies at pre- and post-OPA 90 levels. Net cost savings were calculated as the difference between pre-OPA 90 costs (response costs plus environmental and socioeconomic damages) and post-OPA 90 costs for each spill, following an approach similar to that described by Gautier et al. (2001). Response benefits include cost savings associated with reduced shoreline cleanup, socio-economic, and environmental damage costs with the increase in on-water oil removal.

Assigning per-gallon response, environmental, and socio-economic costs to a spill to perform this analysis such was a difficult task at best. Using generalized values can be misleading as costs are sensitive to oil type, location, and specific operational and environmental 
To be presented at 2003 International Oil Spill Conference, 6 - 10 April 2003

circumstances in each spill (Etkin 1999, 2000). Using bulk values to estimate costs was not very precise from an analytical standpoint, but attempting to estimate response and damage costs for each spill examined would be an enormous undertaking. At the same time, using actual reported spill costs and extrapolating based on oil removal levels was prohibited by incomplete actual cost data, and the often aberrantly high or low costs values due to specific spill circumstances.

A consistent but simple method for calculating "representative costs" if the general spill scenario was encountered in the future was desired. The model adopted for this study is an adaptation of the approach developed for estimating response, environmental, and socioeconomic costs for hypothetical spills in San Francisco Bay (Etkin et al. 2002, 2003; FrenchMcCay et al. 2002). The results of this study were used to derive formulae for per-gallon response costs by method for three oil types - heavy fuel oil (HFO), crude, and diesel (No. 2 fuel), with adjustments for response effectiveness and spill size. This takes into account decreased per-gallon costs for larger spills,, with initial mobilization costs are averaged over a larger volume, as well as lower costs for more efficient removal that prevents shoreline impact and expensive shoreline cleanup. Table 3 reflects total response costs, including on-water operations, spill management/monitoring, and necessary shoreline cleanup.

A similar matrix (Table 4) was developed based on the San Francisco Bay work to assign costs for natural resource damages and socio-economic costs specified by oil type and adjusted for spill size. The current analysis required an assumption that natural resource and socioeconomic damages in the study spills would be analogous to the magnitude of damages that occurred in San Francisco Bay. While it is recognized that actual spill location has a tremendous impact on environmental and socio-economic damages, applying the study spills to this one welldocumented and already modeled location, in essence, "normalizes" the differences in actual locations between the spills in projecting to future potential spills. Here again, the objective of 
To be presented at 2003 International Oil Spill Conference, 6 - 10 April 2003

this analysis was to provide representative quantitative measures of progress and not precise cost savings for each spill. Detailed modeling of environmental and socio-economic damages for the actual spills was prohibitively expensive and reported cost data on these spills is incomplete.

For each past spill analyzed, the response costs and damage costs were then calculated using Tables 3 and 4, based on the effectiveness level. Environmental and socio-economic damages were reduced based on $\%$ on-water oil removal. Total costs for each spill were calculated at preand post-OPA 90 levels of effectiveness for mechanical recovery, in-situ burning, and dispersants. Net cost savings were calculated by subtracting post-OPA 90 costs from pre-OPA 90 costs. The difference represents cost savings associated with more efficient oil removal and reduced costs associated with decreased socio-economic and environmental impact.

\section{RESULTS}

The cost saving analysis of the CAPS spills (Table 5) shows that for the 35 spills investigated, cleanup operations were possible in 19 spills that involved a total of 485,529 gallons of spilled oil. Mechanical recovery was applicable in 15 cases, dispersants were applicable in eight, and in-situ burning was applicable in six. The total net cost savings associated with development and application of augmented mechanical recovery (effectiveness increase from $20 \%$ to $50 \%$ ) is $\$ 95.7$ million. The total net cost savings associated with dispersant development and application is \$38.1 million. In-situ burning development and application accounted for a $\$ 46.5$ million net cost savings.

The cost savings results for the OSPPR spills are in Tables $6-8$ for mechanical recovery, dispersants and in-situ burning. For the 28 medium and major spills investigated, cleanup operations were possible in 22 spills involving 15,009,500 gallons of oil. Mechanical recovery was applicable in 22 cases, dispersants were applicable in three, and in-situ burning was applicable in five. Total net cost savings associated with development and application of augmented mechanical recovery (effectiveness increase from $10-20 \%$ to $20-50 \%$ ) was $\$ 633.9$ 
To be presented at 2003 International Oil Spill Conference, 6 - 10 April 2003

million. Dispersant development and application accounted for \$323.1 million and in-situ burning development and application accounted for \$755.5 million net cost savings.

\section{CONCLUSIONS}

The analysis results are summarized in Table 9. For the medium spill scenarios represented by the CAPS spill set, the highest net cost savings is accrued from advanced mechanical recovery technology (\$95.7 million), assuming a 50\% effectiveness level. Net cost savings from dispersants and in-situ burning are roughly equivalent at \$38.1 million and \$46.5 million, respectively. Even though the oil volume represented by these spills is small (485,000 gallons), it appears that a substantial net cost savings would be realized if a similar future spill set could be responded to at the proposed effectiveness levels. For the OSPPR spills (representing 15 million gallons.of spilled oil), the results are similar with the net cost savings accrued from advanced mechanical recovery technology of $\$ 634$ million, assuming a $20-50 \%$ effectiveness level. Net cost savings from dispersants and in-situ burning are \$325 million and \$755 million, respectively. Mechanical recovery net cost savings are proportionally lower than for the CAPS set, as the effectiveness level varies from $20 \%$ to $50 \%$, while it was kept constant at $50 \%$ for the CAPS spills. A substantial savings is noted for in-situ burning, as there were several high volume spills in the OSPPR spill set where the technique was deemed applicable. The low on-water response cost for this oil-removal technology contributes to the high net cost savings.

Viewed together, the results suggest that the potential net cost savings that could be realized by R\&D for these removal technologies over the past decade is substantial. From the OSPPR spill set analysis, it appears that net cost savings may be on the order of hundreds of millions of dollars assuming that similar spills were to occur in the next decade. This represents a substantial return on investment given that the expenditures on US oil spill R\&D have probably not exceeded $\$ 100$ million over the past decade. It also suggests that further significant gains can be made by modest expenditures in oil spill response technology development. 
To be presented at 2003 International Oil Spill Conference, 6 - 10 April 2003

\section{ACKNOWLEDGEMENTS}

This project is an extension by-product of research funded by the USCG Headquarters Office of

Response and ongoing projects of the USCG Research and Development Center, Groton, CT.

\section{BIOGRAPHY}

Dagmar Schmidt Etkin received her B.A. in Biology from University of Rochester, and her A.M.

and Ph.D. in Biology (specializing in population biology, ecology, and statistical analysis) from

Harvard University. She has analyzed and modeled oil spill data and impacts for 15 years.

\section{REFERENCES}

Allen, A.A., and R.J. Ferek. 1993. Advantages and disadvantages of burning spilled oil. Proc. 1993 International Oil Spill Conference: 765 - 772.

Etkin, D.S. 1999. Estimating cleanup costs for oil spills. Proc. 1999 International Oil Spill Conference: $35-39$.

Etkin, D.S. 2000. Worldwide analysis of oil spill cleanup cost factors. Proc. $23^{\text {rd }}$ Arctic \& Marine Oilspill Prog. Tech. Sem.: $161-174$.

Etkin, D.S. D. French-McCay, J. Jennings, N. Whittier, S. Subbayya, W. Saunders, C. Dalton. 2003. Financial implications of hypothetical San Francisco Bay oil spill scenarios: response, socioeconomic, and natural resource damage costs. Proc. 2003 International Oil Spill Conference: (current volume)

Etkin, D.S., D.French-McCay, N. Whittier, S. Subbayya, and J. Jennings. 2002. Modeling of response, socioeconomic, and natural resource damage costs for hypothetical oil spill scenarios in San Francisco Bay. Proc. 25th Arctic \& Marine Oilspill Prog. Tech. Sem.: $1,075-1,102$.

French-McCay, D., N.Whittier, S. Subbayya, J. Jennings, and D.S. Etkin. 2002. Modeling fates and impacts for bio-economic analysis of hypothetical oil spill scenarios in San Francisco Bay. Proc. 25th Arctic \& Marine Oilspill Program Tech. Sem.: 1,051 - 1,074.

Gautier, P., K. Satra, J.Tarpley, H. Henderson, H. Parker-Hall, and E. Ueber. 2001. Response benefit analysis: A new method for measuring response effectiveness. Proc. 2001 International Oil Spill Conference: 497 - 503.

Kucklick, J.H., and D. Aurand. 1997. Historical dispersant and in-situ burning opportunities in the United States. Proc. 1997 International Oil Spill Conference: $805-810$.

Lewis, A. and D. Aurand. 1997. Putting Dispersants to Work: Overcoming Obstacles. 1997 International Oil Spill Conference Issue Paper. American Petroleum Institute Technical Report IOSC-004, 78 pp.

National Oceanic and Atmospheric Administration (NOAA). 1998. Spill Tools: Dispersant Mission Planner. NOAA, Office of Response and Restoration, Hazardous Materials Response Division, Seattle, Washington, USA. 
To be presented at 2003 International Oil Spill Conference, 6 - 10 April 2003

Pond, R.G., D.V. Aurand, and J.A. Kraly. 2000. Ecological Risk Assessment Principles Applied to Oil Spill Response Planning in the San Francisco Bay Area. California Office Spill Prevention and Response, Dept. Fish and Game, Sacramento, California, USA, 200 pp.

US Coast Guard. 1999. Response Plan Equipment Caps Review. Draft report. August 1999. US Coast Guard Commandant, Office of Response, Washington, DC, USA.

US Coast Guard. 2001. Risk Assessment for the Coast Guard's Oil Spill Prevention, Preparedness, and Response (OSPPR) Program: Phase I: Concept Development, Risk Characterization, and Issue Identification. USCG Office of Response, Washington, DC, USA. DTCG23-00-MM3A01. 239 pp. 
To be presented at 2003 International Oil Spill Conference, 6 - 10 April 2003

FIGURES

\begin{tabular}{|c|c|c|c|c|c|c|c|}
\hline \multicolumn{8}{|c|}{$\begin{array}{l}\text { Table 1: Spills from the CAPS Study Analyzed for Cost Savings } \\
\text { Using Mechanical Recovery, Dispersants and In-Situ Burning }\end{array}$} \\
\hline \multirow{2}{*}{$\begin{array}{l}\text { Vessel } \\
\text { Name }\end{array}$} & \multirow{2}{*}{$\begin{array}{l}\text { Qty. } \\
\text { Spilled } \\
\text { (Gals.) }\end{array}$} & \multirow{2}{*}{ Oil Type } & \multicolumn{5}{|c|}{$\begin{array}{c}\text { Applicability of Oil Removal Methods } \\
\text { for Existing and Expanded Criteria }\end{array}$} \\
\hline & & & $\begin{array}{l}\text { Mech. } \\
\text { Recov. }\end{array}$ & $\begin{array}{l}\text { Disp. } \\
\text { Exist. }\end{array}$ & $\begin{array}{l}\text { Disp. } \\
\text { Exp. }\end{array}$ & $\begin{array}{c}\text { ISB } \\
\text { Exist. }\end{array}$ & $\begin{array}{l}\text { ISB } \\
\text { Exp. }\end{array}$ \\
\hline New Janet Ann & 11,000 & Diesel & $\mathrm{N}$ & $\mathrm{N}$ & $\mathrm{Y}$ & $\mathrm{N}$ & $\mathrm{N}$ \\
\hline Sea-Land Hawaii & 25,200 & Waste/Lube & $\mathrm{Y}$ & $\mathrm{Y}$ & $\mathrm{Y}$ & $\mathrm{Y}$ & $\mathrm{Y}$ \\
\hline Frances Lee & 16,000 & Diesel & $\mathrm{Y}$ & $\mathrm{N}$ & $\mathrm{N}$ & $\mathrm{N}$ & $\mathrm{N}$ \\
\hline Barge 155/Capt. Bouchard & 330,000 & No. 6 Fuel & $\mathrm{N}$ & $\mathrm{N}$ & $\mathrm{N}$ & $\mathrm{N}$ & $\mathrm{N}$ \\
\hline Jin Shing Fa & 96,000 & Lube & $\mathrm{Y}$ & $\mathrm{N}$ & $\mathrm{N}$ & $\mathrm{N}$ & $\mathrm{N}$ \\
\hline Morris J. Berman & 750,000 & No. 6 Fuel & $\mathrm{N}$ & $\mathrm{N}$ & $\mathrm{N}$ & $\mathrm{N}$ & $\mathrm{N}$ \\
\hline IB 20131 & 40,150 & Asphalt & $\mathrm{N}$ & $\mathrm{N}$ & $\mathrm{N}$ & $\mathrm{N}$ & $\mathrm{N}$ \\
\hline Chevak & 12,000 & Diesel & $\mathrm{N}$ & $\mathrm{N}$ & $\mathrm{N}$ & $\mathrm{N}$ & $\mathrm{N}$ \\
\hline Bow Sun & 35,700 & No. 6 Fuel & $\mathrm{N}$ & $\mathrm{N}$ & $\mathrm{N}$ & $\mathrm{N}$ & $\mathrm{N}$ \\
\hline Umqua Fisher & 20,000 & Diesel & $\mathrm{Y}$ & $\mathrm{N}$ & $\mathrm{N}$ & $\mathrm{N}$ & $\mathrm{N}$ \\
\hline RTC 20 & 15,000 & Waste/Lube & $\mathrm{Y}$ & $\mathrm{N}$ & $\mathrm{Y}$ & $\mathrm{N}$ & $\mathrm{Y}$ \\
\hline Island Enterprise & 12,705 & Diesel & $\mathrm{N}$ & $\mathrm{Y}$ & $\mathrm{Y}$ & $\mathrm{N}$ & $\mathrm{N}$ \\
\hline USS Inchon & 19,000 & Diesel & $\mathrm{N}$ & $\mathrm{N}$ & $\mathrm{N}$ & $\mathrm{N}$ & $\mathrm{N}$ \\
\hline Barge 101/Mercury & 26,000 & Diesel & $\mathrm{Y}$ & $\mathrm{N}$ & $\mathrm{N}$ & $\mathrm{N}$ & $\mathrm{N}$ \\
\hline Skaubay/Berge Banker & 37,716 & No. 6 Fuel & $\mathrm{N}$ & $\mathrm{N}$ & $\mathrm{N}$ & $\mathrm{N}$ & $\mathrm{N}$ \\
\hline Mormac Star & 15,918 & No. 2 Fuel & $\mathrm{Y}$ & $\mathrm{N}$ & $\mathrm{N}$ & $\mathrm{N}$ & $\mathrm{N}$ \\
\hline American Express & 12,500 & Diesel & $\mathrm{N}$ & $\mathrm{N}$ & $\mathrm{Y}$ & $\mathrm{N}$ & $\mathrm{N}$ \\
\hline Leslie & 13,062 & Naptha & $\mathrm{N}$ & $\mathrm{N}$ & $\mathrm{N}$ & $\mathrm{N}$ & $\mathrm{N}$ \\
\hline Interstate 138 & 92,610 & No. 6 Fuel & $\mathrm{N}$ & $\mathrm{N}$ & $\mathrm{N}$ & $\mathrm{N}$ & $\mathrm{N}$ \\
\hline Northern Wind & 20,000 & Diesel & $\mathrm{Y}$ & $\mathrm{N}$ & $\mathrm{N}$ & $\mathrm{N}$ & $\mathrm{N}$ \\
\hline M.B. McAllister & 25,000 & Diesel & $\mathrm{Y}$ & $\mathrm{Y}$ & $\mathrm{Y}$ & $\mathrm{Y}$ & $\mathrm{Y}$ \\
\hline Defiant & 30,000 & Diesel & $\mathrm{Y}$ & $\mathrm{N}$ & $\mathrm{N}$ & $\mathrm{N}$ & $\mathrm{N}$ \\
\hline North Cape & 828,000 & No. 2 Fuel & $\mathrm{N}$ & $\mathrm{N}$ & $\mathrm{N}$ & $\mathrm{N}$ & $\mathrm{N}$ \\
\hline Buffalo 292 & 176,400 & No. 6 Fuel & $\mathrm{N}$ & $\mathrm{N}$ & $\mathrm{N}$ & $\mathrm{N}$ & $\mathrm{N}$ \\
\hline Anitra & 40,000 & Crude Oil & $\mathrm{Y}$ & $\mathrm{N}$ & $\mathrm{N}$ & $\mathrm{N}$ & $\mathrm{Y}$ \\
\hline Buffalo 286 & 25,998 & No. 6 Fuel & $\mathrm{N}$ & $\mathrm{N}$ & $\mathrm{N}$ & $\mathrm{N}$ & $\mathrm{N}$ \\
\hline Unknown Vessel & 12,000 & Crude Oil & $\mathrm{Y}$ & $\mathrm{N}$ & $\mathrm{N}$ & $\mathrm{N}$ & $\mathrm{N}$ \\
\hline Rosie G & 16,000 & Diesel & $\mathrm{N}$ & $\mathrm{Y}$ & $\mathrm{Y}$ & $\mathrm{N}$ & $\mathrm{N}$ \\
\hline BFT No. 39 & 27,636 & Gasoline & $\mathrm{N}$ & $\mathrm{N}$ & $\mathrm{N}$ & $\mathrm{N}$ & $\mathrm{N}$ \\
\hline Barge No. 125 & 26,460 & Gasoline & $\mathrm{N}$ & $\mathrm{N}$ & $\mathrm{N}$ & $\mathrm{N}$ & $\mathrm{N}$ \\
\hline Kure & 40,000 & Diesel & $\mathrm{Y}$ & $\mathrm{N}$ & $\mathrm{N}$ & $\mathrm{N}$ & $\mathrm{N}$ \\
\hline Barge No. 125 & 39,000 & No. 6 Fuel & $\mathrm{N}$ & $\mathrm{N}$ & $\mathrm{N}$ & $\mathrm{N}$ & $\mathrm{N}$ \\
\hline Stone Fuller & 31,206 & Crude Oil & $\mathrm{Y}$ & $\mathrm{N}$ & $\mathrm{Y}$ & $\mathrm{N}$ & $\mathrm{Y}$ \\
\hline Red Seagull & 21,000 & Med. Crude & $\mathrm{Y}$ & $\mathrm{N}$ & $\mathrm{N}$ & $\mathrm{Y}$ & $\mathrm{Y}$ \\
\hline Rosellen & 14,300 & Vegetable & $\mathrm{N}$ & $\mathrm{N}$ & $\mathrm{N}$ & $\mathrm{N}$ & $\mathrm{N}$ \\
\hline \multicolumn{8}{|c|}{$\begin{array}{l}\text { TY and } \mathrm{N} \text { (yes or no) indicate whether oil removal method potentially applicable under conditions } \\
\text { described for spill and application criteria specified. For dispersants and in-situ burning, two } \\
\text { application criteria considered: Existing Criteria ( } \geq 3 \text { nautical miles from shore) and Expanded } \\
\text { Criteria ( } \geq 1 / 4 \text { mile from shore). }\end{array}$} \\
\hline
\end{tabular}

Etkin and Tebeau IOSC 2003 Paper Pre-Publication Copy - DO NOT CITE OR QUOTE 12 
To be presented at 2003 International Oil Spill Conference, 6 - 10 April 2003

\begin{tabular}{|c|c|c|c|c|c|c|}
\hline \multicolumn{7}{|c|}{$\begin{array}{c}\text { Table 2: Spills from the OSPPR Study Analyzed for Cost Savings } \\
\text { Using Mechanical Recovery, Dispersants and In-Situ Burning }\end{array}$} \\
\hline $\begin{array}{l}\text { Source } \\
\end{array}$ & Location & Volume (gal) & Oil Type & Mech & Disp & ISB \\
\hline \multicolumn{7}{|l|}{ Tankers } \\
\hline World Prodigy & coast/harbor & 294,000 & No. 2 fuel & $\mathrm{N}$ & $\mathrm{N}$ & $\mathrm{N}$ \\
\hline President Rivera & river/harbor & 300,000 & No. 6 fuel & $\mathrm{Y}$ & $\mathrm{N}$ & $\mathrm{N}$ \\
\hline American Trader & coast/harbor & 417,000 & light crude & $\mathrm{Y}$ & $\mathrm{Y}$ & $\mathrm{Y}$ \\
\hline Mega Borg & offshore/ocean & $5,000,000$ & light crude & $\mathrm{Y}$ & $\mathrm{Y}$ & $\mathrm{Y}$ \\
\hline Jupiter & river & 840,000 & Gasoline & $\mathrm{N}$ & $\mathrm{N}$ & $\mathrm{N}$ \\
\hline Julie N & river/harbor & 180,000 & No.2/No.6 fuel & $\mathrm{Y}$ & $\mathrm{N}$ & $\mathrm{N}$ \\
\hline Cape Mohican & bay/harbor & 98,000 & No. 6 fuel & $\mathrm{Y}$ & $\mathrm{N}$ & $\mathrm{N}$ \\
\hline Command & offshore/ocean & 51,500 & No. 6 fuel & $\mathrm{N}$ & $\mathrm{N}$ & $\mathrm{N}$ \\
\hline \multicolumn{7}{|l|}{ Barges } \\
\hline Bouchard 155 & coast/bay & 333,000 & No. 6 fuel & $\mathrm{Y}$ & $\mathrm{N}$ & $\mathrm{N}$ \\
\hline Morris Berman & nearshore/coast & 789,000 & No. 6 fuel & $\mathrm{Y}$ & $\mathrm{N}$ & $\mathrm{N}$ \\
\hline North Cape & nearshore/coast & 828,000 & No. 2 fuel & $\mathrm{Y}$ & $\mathrm{N}$ & $\mathrm{N}$ \\
\hline Buffalo 292 & nearshore/coast & 189,000 & IFO & $\mathrm{Y}$ & $\mathrm{N}$ & $\mathrm{N}$ \\
\hline Buffalo 286 & nearshore/coast & 42,000 & No. 6 fuel & $\mathrm{Y}$ & $\mathrm{N}$ & $\mathrm{N}$ \\
\hline RTC 320 & harbor & 50,000 & No. 6 fuel & $\mathrm{Y}$ & $\mathrm{N}$ & $\mathrm{N}$ \\
\hline \multicolumn{7}{|l|}{ Offshore Platform } \\
\hline Greenhill Well & offshore/ocean & 687,000 & crude & $\mathrm{Y}$ & $\mathrm{N}$ & $\mathrm{N}$ \\
\hline \multicolumn{7}{|c|}{ Freighters and Fishing Vessels } \\
\hline $\begin{array}{l}\text { Sammi Superstars/ } \\
\text { Maui }\end{array}$ & harbor & 32,000 & No. 6 fuel & $\mathrm{Y}$ & $\mathrm{N}$ & $\mathrm{N}$ \\
\hline Tenyo Maru & offshore/ocean & 173,000 & IFO, No. 2 fuel & $\mathrm{Y}$ & $\mathrm{N}$ & $\mathrm{N}$ \\
\hline Citrus & offshore/coast & 9,000 & No. 5 fuel & $\mathrm{N}$ & $\mathrm{N}$ & $\mathrm{N}$ \\
\hline Kure & coast/harbor & 4,500 & IFO & $\mathrm{Y}$ & $\mathrm{N}$ & $\mathrm{N}$ \\
\hline Kuroshima & offshore/coast & 47,000 & No. 2/No. 6 fuel & $\mathrm{N}$ & $\mathrm{N}$ & $\mathrm{N}$ \\
\hline Star Evviva & offshore/ocean & 24,000 & No. 6 fuel & $\mathrm{N}$ & $\mathrm{N}$ & $\mathrm{N}$ \\
\hline New Carissa & nearshore/coast & 70,000 & No.2/No.4 fuel & $\mathrm{Y}$ & $\mathrm{N}$ & $\mathrm{Y}$ \\
\hline \multicolumn{7}{|l|}{ Onshore Facility } \\
\hline $\begin{array}{l}\text { Texaco Anacortes } \\
\text { Refinery }\end{array}$ & harbor & 210,000 & crude & Y & $\mathrm{N}$ & $\mathrm{N}$ \\
\hline \multicolumn{7}{|l|}{ Pipelines } \\
\hline Exxon Bayway & harbor & 567,000 & No. 2 fuel & $\mathrm{Y}$ & $\mathrm{N}$ & $\mathrm{N}$ \\
\hline Colonial, Potomac & river & 407,000 & No. 2 fuel & $\mathrm{Y}$ & $\mathrm{N}$ & $\mathrm{N}$ \\
\hline $\begin{array}{l}4 \text { Pipelines, } \\
\text { San Jacinto R. }\end{array}$ & river & $1,616,000$ & No.2 fuel, crude & $\mathrm{Y}$ & $\mathrm{N}$ & $\mathrm{Y}$ \\
\hline Chevon, Oahu & coast/harbor & 41,000 & No. 6 fuel & $\mathrm{Y}$ & $\mathrm{N}$ & $\mathrm{N}$ \\
\hline Texaco, Lake Barre & nearshore/coast & 276,000 & crude & $\mathrm{Y}$ & $\mathrm{Y}$ & $\mathrm{Y}$ \\
\hline
\end{tabular}


To be presented at 2003 International Oil Spill Conference, 6 - 10 April 2003

\begin{tabular}{|c|c|c|c|c|c|c|c|c|c|}
\hline \multicolumn{10}{|c|}{ Table 3: Per-Gallon Oil Spill Response Costs Applied in Cost Savings Analysis ${ }^{1}$} \\
\hline \multirow[b]{2}{*}{$\begin{array}{c}\text { Oil } \\
\text { Type }\end{array}$} & \multirow[b]{2}{*}{ Volume (gallons) } & \multicolumn{4}{|c|}{ Mechanical $^{2,4}$} & \multicolumn{2}{|c|}{ Dispersants $^{3,4}$} & \multicolumn{2}{|c|}{ In-Situ Burn ${ }^{5}$} \\
\hline & & $\begin{array}{c}\text { No } \\
\text { Effect } \\
0 \%\end{array}$ & $\begin{array}{c}\text { Lower } \\
\text { Effect } \\
10 \%\end{array}$ & $\begin{array}{c}\text { Low } \\
\text { Effect } \\
20 \%\end{array}$ & $\begin{array}{c}\text { High } \\
\text { Effect } \\
50 \%\end{array}$ & $\begin{array}{l}\text { Low } \\
\text { Effect }\end{array}$ & $\begin{array}{l}\text { High } \\
\text { Effect }\end{array}$ & $\begin{array}{c}\text { Low } \\
\text { Effect } \\
50 \%\end{array}$ & $\begin{array}{c}\text { High } \\
\text { Effect } \\
80 \%\end{array}$ \\
\hline \multirow{3}{*}{$\begin{array}{l}\text { Light } \\
\text { Fuels }\end{array}$} & $1,000-100,000$ & $\$ 85$ & $\$ 70$ & $\$ 58$ & $\$ 40$ & $\$ 25$ & $\$ 18$ & $\$ 18$ & $\$ 9$ \\
\hline & $100,000-1,000,000$ & $\$ 72$ & $\$ 60$ & $\$ 48$ & $\$ 25$ & $\$ 17$ & $\$ 10$ & $\$ 10$ & $\$ 5$ \\
\hline & $>1,000,000$ & $\$ 30$ & $\$ 25$ & $\$ 17$ & $\$ 12$ & $\$ 11$ & $\$ 6$ & $\$ 7$ & $\$ 3$ \\
\hline \multirow{3}{*}{$\begin{array}{c}\text { Heavy } \\
\text { Fuels }\end{array}$} & $1,000-100,000$ & $\$ 400$ & $\$ 350$ & $\$ 300$ & $\$ 260$ & $\$ 100$ & $\$ 60$ & $\$ 100$ & $\$ 50$ \\
\hline & $100,000-1,000,000$ & $\$ 175$ & $\$ 150$ & $\$ 125$ & $\$ 100$ & $\$ 58$ & $\$ 53$ & $\$ 70$ & $\$ 40$ \\
\hline & $>1,000,000$ & $\$ 85$ & $\$ 75$ & $\$ 65$ & $\$ 35$ & $\$ 52$ & $\$ 48$ & $\$ 55$ & $\$ 25$ \\
\hline \multirow{3}{*}{$\begin{array}{c}\text { Crude } \\
\text { Oil }\end{array}$} & $1,000-100,000$ & $\$ 190$ & $\$ 180$ & $\$ 170$ & $\$ 135$ & $\$ 72$ & $\$ 30$ & $\$ 60$ & $\$ 30$ \\
\hline & $100,000-1,000,000$ & $\$ 120$ & $\$ 115$ & $\$ 110$ & $\$ 90$ & $\$ 48$ & $\$ 28$ & $\$ 35$ & $\$ 16$ \\
\hline & $>1,000,000$ & $\$ 90$ & $\$ 80$ & $\$ 74$ & $\$ 62$ & $\$ 57$ & $\$ 13$ & $\$ 21$ & $\$ 11$ \\
\hline
\end{tabular}

${ }^{1}$ Per-gallon response cost based on hypothetical modeling in Etkin et al. (2002, 2003) with shoreline oil removal costs adjusted by $\%$ reduction of shoreline oiling. Modeling included oil fate by oil type and trajectory with Applied Science Associates' SIMAP (French-McCay et al. 2002).

${ }^{2}$ Per-gallon costs include on-water mechanical recovery, shoreline oil removal, mobilization, and protective booming based on Area Contingency Plan. ${ }^{3}$ Per-gallon costs include on-water dispersant response, shoreline oil removal, mobilization, sensitive site protective booming. ${ }^{4}$ Removal assumed for on-water recovery or dispersants. Shoreline oiling assumed reduced by $\%$ on-water oil removal. Low/high removal by dispersants for diesel/crude $40 \% / 80 \%$, for HFO 35\%/70\% (Pond et al. 2000). ${ }^{5}$ ISB costs based on per-gallon ISB operations costs in Allen and Ferek (1993) updated to $2001 \$$ plus costs of shoreline cleanup of oil not burned.

\begin{tabular}{|c|c|c|c|}
\hline \multicolumn{4}{|c|}{$\begin{array}{l}\text { Table 4: Spill Impact Cost Matrix for Cost Savings Computations } \\
\text { Hypothetical Spill Impact Cost (Assuming No On-Water Response Effectiveness) }\end{array}$} \\
\hline \begin{tabular}{c|c} 
Oil \\
Type
\end{tabular} & Volume (gallons) & $\begin{array}{l}\text { Environmental } \\
\text { \$/gallon }\end{array}$ & $\begin{array}{l}\text { Socioeconomic } \\
\text { \$/gallon }\end{array}$ \\
\hline \multirow{3}{*}{ Gasoline } & $1,000-100,000$ & $\$ 30$ & $\$ 400$ \\
\hline & $100,000-1,000,000$ & $\$ 30$ & $\$ 180$ \\
\hline & $>1,000,000$ & $\$ 10$ & $\$ 90$ \\
\hline \multirow{3}{*}{ Diesel } & $1,000-100,000$ & $\$ 50$ & $\$ 500$ \\
\hline & $100,000-1,000,000$ & $\$ 50$ & $\$ 200$ \\
\hline & $>1,000,000$ & $\$ 20$ & $\$ 100$ \\
\hline \multirow{3}{*}{$\begin{array}{c}\text { Heavy } \\
\text { Fuels }\end{array}$} & $1,000-100,000$ & $\$ 25$ & $\$ 900$ \\
\hline & $100,000-1,000,000$ & $\$ 20$ & $\$ 500$ \\
\hline & $>1,000,000$ & $\$ 10$ & $\$ 200$ \\
\hline \multirow{3}{*}{ Crude } & $1,000-100,000$ & $\$ 140$ & $\$ 300$ \\
\hline & $100,000-1,000,000$ & $\$ 15$ & $\$ 140$ \\
\hline & $>1,000,000$ & $\$ 10$ & $\$ 70$ \\
\hline
\end{tabular}


To be presented at 2003 International Oil Spill Conference, 6 - 10 April 2003

\begin{tabular}{|c|c|c|c|c|c|c|c|}
\hline \multicolumn{6}{|c|}{ Table 5: Results of Cost Savings Analysis for CAPS Spills Over 10,000 Gallons } \\
\hline $\begin{array}{c}\text { Oil Removal } \\
\text { Technology Impact } \\
\text { Examined }\end{array}$ & $\begin{array}{c}\text { Pre }- \text { OPA 90 Spill Costs } \\
\text { (million \$) }\end{array}$ & \multicolumn{2}{|c|}{$\begin{array}{c}\text { Post - OPA 90 Spill Costs } \\
\text { (million \$) }\end{array}$} & $\begin{array}{c}\text { Cost } \\
\text { Savings } \\
\text { (million \$) }\end{array}$ \\
\cline { 2 - 8 } & Resp & Enviro & Socio & Resp & Enviro & Socio \\
\hline $\begin{array}{c}\text { Mechanical } \\
\text { Recovery }\end{array}$ & $\$ 74.3$ & $\$ 24.6$ & $\$ 226.4$ & $\$ 60.5$ & $\$ 17.0$ & $\$ 145.7$ & $\$ 102.1$ \\
\hline $\begin{array}{c}\text { Dispersant } \\
\text { Application }\end{array}$ & $\$ 74.3$ & $\$ 24.6$ & $\$ 226.4$ & $\$ 59.0$ & $\$ 22.1$ & $\$ 206.1$ & $\$ 38.1$ \\
\hline In-Situ Burning & $\$ 74.3$ & $\$ 24.6$ & $\$ 226.4$ & $\$ 54.0$ & $\$ 20.5$ & $\$ 197.9$ & $\$ \mathbf{5 2 . 9}$ \\
\hline
\end{tabular}

\begin{tabular}{|c|c|c|c|c|c|c|c|c|}
\hline \multicolumn{9}{|c|}{ Table 6: Results of Cost Savings Analysis for OSPPR Spills - Mechanical Recovery } \\
\hline \multirow[t]{2}{*}{ Source Type } & \multirow[t]{2}{*}{$\begin{array}{c}\text { No. } \\
\text { Spills }\end{array}$} & \multicolumn{3}{|c|}{$\begin{array}{c}\text { Pre - OPA 90 Spill Costs } \\
\text { (million \$) } \\
\text { Mechanical Recovery } \\
\text { 0-20\% Effectiveness }\end{array}$} & \multicolumn{3}{|c|}{$\begin{array}{c}\text { Post - OPA 90 Spill Costs } \\
\text { (million \$) } \\
\text { Mechanical Recovery } \\
\text { 20- 50\% Effectiveness }\end{array}$} & \multirow[t]{2}{*}{$\begin{array}{c}\text { Cost } \\
\text { Savings } \\
\text { (million \$) }\end{array}$} \\
\hline & & Resp & Enviro & Socio & Resp & Enviro & Socio & \\
\hline Tanker & 8 & $\$ 670.4$ & $\$ 110.5$ & $\$ 1,106.8$ & $\$ 608.6$ & $\$ 101.1$ & $\$ 985.8$ & $\$ 192.2$ \\
\hline Barge & 6 & $\$ 257.2$ & $\$ 61.7$ & $\$ 740.4$ & $\$ 211.7$ & $\$ 50.0$ & $\$ 541.7$ & $\$ 255.9$ \\
\hline Offshore Platform & 1 & $\$ 79.0$ & $\$ 9.3$ & $\$ 86.6$ & $\$ 75.6$ & $\$ 8.2$ & $\$ 76.9$ & $\$ 14.2$ \\
\hline Freighter & 7 & $\$ 95.1$ & $\$ 7.2$ & $\$ 232.1$ & $\$ 85.4$ & $\$ 6.0$ & $\$ 213.0$ & $\$ 30.0$ \\
\hline Shore Facility & 1 & $\$ 24.2$ & $\$ 2.8$ & $\$ 26.5$ & $\$ 21.0$ & $\$ 2.5$ & $\$ 23.5$ & $\$ 6.5$ \\
\hline Pipeline & 5 & $\$ 223.5$ & $\$ 57.5$ & $\$ 383.9$ & $\$ 189.8$ & $\$ 45.8$ & $\$ 294.9$ & $\$ 134.4$ \\
\hline TOTAL & 28 & $\$ 1,349.4$ & $\$ 249.0$ & $\$ 2,576.3$ & $\$ 1,192.1$ & $\$ 213.6$ & $\$ 2,135.8$ & $\$ 633.9$ \\
\hline
\end{tabular}

\begin{tabular}{|c|c|c|c|c|c|c|c|c|}
\hline \multicolumn{9}{|c|}{ Table 7: Results of Cost Savings Analysis for OSPPR Spills - Dispersants } \\
\hline \multirow[t]{2}{*}{ Source Type } & \multirow[t]{2}{*}{$\begin{array}{c}\text { No. } \\
\text { Spills }\end{array}$} & \multicolumn{3}{|c|}{$\begin{array}{c}\text { Pre - OPA 90 Spill Costs } \\
\text { (million \$) } \\
\text { Mechanical Recovery } \\
\text { 0-20\% Effectiveness }\end{array}$} & \multicolumn{3}{|c|}{$\begin{array}{c}\text { Post - OPA 90 Spill Costs } \\
\text { (million \$) } \\
\text { Dispersants Available } \\
\text { 35-40\% Effectiveness }\end{array}$} & \multirow[t]{2}{*}{$\begin{array}{c}\text { Cost } \\
\text { Savings } \\
\text { (million \$) }\end{array}$} \\
\hline & & Resp & Enviro & Socio & Resp & Enviro & Socio & \\
\hline Tanker & 8 & $\$ 670.4$ & $\$ 110.5$ & $\$ 1,106.8$ & $\$ 527.4$ & $\$ 94.3$ & $\$ 990.1$ & $\$ 275.9$ \\
\hline Barge & 6 & $\$ 257.2$ & $\$ 61.7$ & $\$ 740.4$ & $\$ 257.2$ & $\$ 61.7$ & $\$ 740.4$ & \$0 \\
\hline Offshore Platform & 1 & $\$ 79.0$ & $\$ 9.3$ & $\$ 86.6$ & $\$ 79.0$ & $\$ 9.3$ & $\$ 86.6$ & \$0 \\
\hline Freighter & 7 & $\$ 95.1$ & $\$ 7.2$ & $\$ 232.1$ & $\$ 95.1$ & $\$ 7.2$ & $\$ 232.1$ & $\$ 0$ \\
\hline Shore Facility & 1 & $\$ 24.2$ & $\$ 2.8$ & $\$ 26.5$ & $\$ 24.2$ & $\$ 2.8$ & $\$ 26.5$ & \$0 \\
\hline Pipeline & 5 & $\$ 223.5$ & $\$ 57.5$ & $\$ 383.9$ & $\$ 189.0$ & $\$ 53.1$ & $\$ 273.5$ & $\$ 47.2$ \\
\hline TOTAL & 28 & $\$ 1,349.4$ & $\$ 249.0$ & $\$ 2,576.3$ & $\$ 1,139.9$ & $\$ 226.7$ & $\$ 2,280.8$ & $\$ 323.1$ \\
\hline
\end{tabular}


To be presented at 2003 International Oil Spill Conference, 6 - 10 April 2003

\begin{tabular}{|c|c|c|c|c|c|c|c|c|}
\hline \multicolumn{9}{|c|}{ Table 8: Results of Cost Savings Analysis for OSPPR Spills - In-Situ Burning } \\
\hline \multirow[t]{2}{*}{ Source Type } & \multirow[t]{2}{*}{$\begin{array}{c}\text { No. } \\
\text { Spills }\end{array}$} & \multicolumn{3}{|c|}{$\begin{array}{c}\text { Pre - OPA 90 Spill Costs } \\
\text { (million \$) } \\
\text { Mechanical Recovery } \\
\text { 0-20\% Effectiveness }\end{array}$} & \multicolumn{3}{|c|}{$\begin{array}{c}\text { Post - OPA 90 Spill Costs } \\
\text { (million \$) } \\
\text { In-Situ Burning } \\
\text { Available } \\
50 \% \text { Effectiveness } \\
\end{array}$} & \multirow[t]{2}{*}{$\begin{array}{c}\text { Cost } \\
\text { Savings } \\
(\text { million \$) }\end{array}$} \\
\hline & & Resp & Enviro & Socio & Resp & Enviro & Socio & \\
\hline Tanker & 8 & $\$ 670.4$ & $\$ 110.5$ & $\$ 1,106.8$ & $\$ 342.0$ & $\$ 88.6$ & $\$ 949.3$ & $\$ 507.8$ \\
\hline Barge & 6 & $\$ 257.2$ & $\$ 61.7$ & $\$ 740.4$ & $\$ 257.2$ & $\$ 61.7$ & $\$ 740.4$ & 0 \\
\hline Offshore Platform & 1 & $\$ 79.0$ & $\$ 9.3$ & $\$ 86.6$ & $\$ 79.0$ & $\$ 9.3$ & $\$ 86.6$ & $\mathbf{0}$ \\
\hline Freighter & 7 & $\$ 95.1$ & $\$ 7.2$ & $\$ 232.1$ & $\$ 77.6$ & $\$ 6.5$ & $\$ 206.9$ & $\$ 43.4$ \\
\hline Shore Facility & 1 & $\$ 24.2$ & $\$ 2.8$ & $\$ 26.5$ & $\$ 24.2$ & $\$ 2.8$ & $\$ 26.5$ & $\mathbf{0}$ \\
\hline Pipeline & 5 & $\$ 223.5$ & $\$ 57.5$ & $\$ 383.9$ & $\$ 99.3$ & $\$ 51.3$ & $\$ 310.0$ & $\$ 204.3$ \\
\hline TOTAL & 28 & $\$ 1,349.4$ & $\$ 249.0$ & $\$ 2,576.3$ & $\$ 879.3$ & $\$ 220.2$ & $\$ 2,319.7$ & $\$ 755.5$ \\
\hline
\end{tabular}

\begin{tabular}{|c|c|c|c|c|c|}
\hline \multicolumn{6}{|c|}{ Table 9: Cost Benefits From Response Technology Research and Development } \\
\hline \multirow[b]{2}{*}{$\begin{array}{l}\text { Response } \\
\text { Type }\end{array}$} & \multirow[b]{2}{*}{ Spill Set } & \multicolumn{4}{|c|}{ Cost Savings (million \$) Compared to Pre-OPA 90} \\
\hline & & $\begin{array}{c}\text { Response } \\
\text { Cost } \\
\end{array}$ & $\begin{array}{c}\text { Environmental } \\
\text { Damages }\end{array}$ & $\begin{array}{c}\text { Socioeconomic } \\
\text { Damages }\end{array}$ & Total \\
\hline \multirow{2}{*}{$\begin{array}{l}\text { Augmented } \\
\text { Mechanical }\end{array}$} & OSPPR & $\$ 157.3$ & $\$ 35.4$ & $\$ 440.5$ & $\$ 633.9$ \\
\hline & CAPS & $\$ 13.8$ & $\$ 7.6$ & $\$ 80.7$ & $\$ 102.1$ \\
\hline \multirow{2}{*}{$\begin{array}{l}\text { Dispersant } \\
\text { Application }\end{array}$} & OSPPR & $\$ 177.5$ & $\$ 20.6$ & $\$ 227.1$ & $\$ 323.1$ \\
\hline & CAPS & $\$ 15.3$ & $\$ 2.5$ & $\$ 20.3$ & $\$ 38.1$ \\
\hline \multirow{2}{*}{$\begin{array}{c}\text { In-Situ } \\
\text { Burning }\end{array}$} & OSPPR & $\$ 470.1$ & $\$ 28.8$ & $\$ 256.6$ & $\$ 755.5$ \\
\hline & CAPS & $\$ 20.3$ & $\$ 4.1$ & $\$ 28.5$ & $\$ 52.9$ \\
\hline
\end{tabular}

